\title{
JUURNAL.RU
}

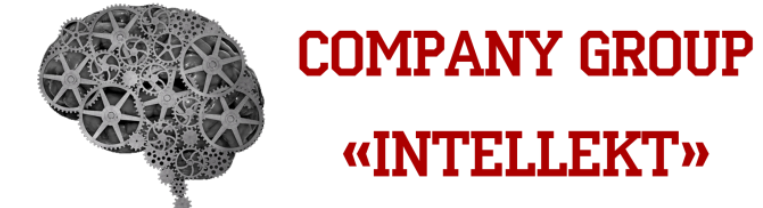

Ромейко К.А. Государственный Университет Управления

Россия

doi: 10.18411/1j2016-5-3-15

\section{Международная логистика как двигатель процесса глобализации}

Аннотация. В данной статье дается описание международной логистики и международной торговли, рассматриваются факторы, стимулирующие развитие экспорта и импорта товаров, а также риски, возникающие при осуществлении подобной деятельности. Международная торговля и логистика рассматриваются как двигатель процесса глобализации.

Ключевые слова: Логистика, международная торговля, международная логистика, интеграция, глобализация, импорт, экспорт, международные перевозки.

Сегодня в науке и на практике все большую популярность завоевывают так называемые междисциплинарные подходы к решению научных и прикладных задач. В сфере экономики одним из таких направлений выступает наука логистика, которая синтезирует кибернетику и системотехнику, менеджмент и маркетинг, теорию массового обслуживания, исследование операций и многое др.

Международная логистика стала своеобразным ответом на вызов постоянно движущегося вперед времени, суть которого можно охарактеризовать как создание универсального инструментария для решения комплекса проблем, которые возникают в процессе продвижения продукции из сферы производства в сферу потребления, включая рациональное использование ресурсов как в 
самом производстве, так и в потреблении. Именно поэтому международная торговля всегда связана с определенными трудностями, угрозами и рисками, поскольку даже при самой простой трансакции международная торговля развивается очень быстро. Все ее составляющие зависят именно от эффективности логистики, занимающейся перемещением товаров по всему миру.

В настоящее время существует несколько способов выхода на международные рынки. Разные компании могут организовать свои международные операции разными способами. У каждого из них свои преимущества, определяющие конкретные особенности ведения логистической деятельности. Тем не менее, наблюдается общая тенденция к глобальным операциям, когда весь мир рассматривается как потребления, включая рациональное использование ресурсов как в самом производстве, так и в потреблении. Международная торговля всегда связана с определенными трудностями, угрозами и рисками, поскольку даже при самой простой трансакции международная торговля развивается очень быстро. Bce eе составляющие зависят именно от эффективности логистики, занимающейся перемещением товаров по всему миру.

Так каковы же основные факторы, стимулирующие международную логистику и торговлю? Выделим основные:

1.Увеличение спроса на новых рынках. Растет уровень жизни населения, увеличивается кол-во потребителей. Иностранные компании выявляют платежеспособные возможности на растущих рынках и расширяют там свою деятельность, продавая все больше продукции.

2.Рост спроса на иностранные продукты. Процесс глобализации и интернационализации способствует увеличению спроса на зарубежные товары

3.Устранение торговых барьеров. Генеральное соглашение по тарифам и торговле (ГАТТ), считающее, что все его члены одинаковы и на этой основе с ними строятся равноправные экономические отношения. В ряде регионов 
государства создали свободные торговые территории (зоны, оффшоры).

4.Экономия на масштабах. Оптимальный выпуск продукции связан с масштабным производством, централизованное производство позволяет получить более низкие затраты на единицу продукции в размере, который позволяет покрыть собой рост логистических издержек

5.Специализированная поддержка. Организации концентрируются все чаще на своих ключевых компетенциях, а остальные виды деятельности передают на аутсорсинг.

6.Рост объемов сервисных услуг на национальных рынках. Концентрация на сервисных услугах по предпродажному и после продажному обслуживанию, сопровождение в эксплуатации вплоть до конечной утилизации после морального и физического износа.

7.Интеграция цепи поставок. Интеграция работает на обеспечение более плавного и оперативного перемещения продукции от поставщиков начального уровня до конечных потребителей.

8.Рост спроса на поставщиков. Потребители повышают спрос и требования к поставщикам: на операции «точно в срою), комплексное качество, стратегические союзы, массовое производство на заказ.

9.Изменения логистических приемов. Развитие контейнеризации (разные типоразмеры, применяемые материалы, жесткие, мягкие и т. д.). отсрочка коммерческих операций до полной доводки продукции в конечных точках цепи поставок позволяет гибко реагировать на спрос потребителей.

10.Улучшение коммуникаций с потребителями. Спутниковое телевидение, Интернет и мобильные каналы коммуникаций помогают потребителям лучше разбираться в продукции, изготавливаемой за пределами их регионов проживания.

11.Совершенствование коммуникаций в бизнесе. Новые разработки в спутниковой и мобильной связи, коммуникациях, информационных системах.

12.Степень соответствия продукции условиям международной торговли. 
Относительно высокая удельная стоимость товарного груза (отношение стоимости товарного продукта к его весу или размеру - "value density").

Следует особо отметить, что все больше компаний в настоящее время понимает это и начинает работать в международных масштабах, на определенном уровне осваивая разные национальные рынки. Правительства практически всех государств оказывают всестороннюю поддержку развитию международной торговли и, соответственно, международных перевозок. Этому способствуют такие международные соглашения, как Генеральное соглашение по тарифам и торговле (ГАТТ), Гаагская, Венские конвенции. Конвенция ООН. Организация экономического сотрудничества и развития (ОЭСР), Всемирная торговая организация (ВТО). Комитет Всемирной таможенной организации. Соглашения по гармонизированной системе кодирования товаров (Товарная номенклатура ВЭД).

В заключение следует отметить, что в наш век глобализации международная торговля, а следовательно, и международная логистика стремительно развиваются, и именно неравномерность развития отдельных отраслей в разных странах способствует импорту и экспорту. Появляется тенденция к безграничному расширению размеров производства, поэтому производство неизбежно перерастает границы внутреннего спроса, и предприниматели каждой страны ведут упорную борьбу за внешние рынки. Росту темпов международного товарообмена и, как следствие, международной логистики способствовала также интеграция, поскольку были отменены ограничения в торговле между этими странами, на которые приходится почти половина объема мировой торговли.

Кроме того, в структуре международной торговли произошли изменения под воздействием научно-технической революции, ускорившей процесс международного разделения труда и вызвавшей рост обмена наукоемкой продукцией, готовыми изделиями и услугами. 


\section{Литература}

1. Воронов, В. И. Международная логистика (Электронный ресурс) // ГУУ. - M. 2014. - 700 C.

2. Воронов. В. И., Воронов. А. В.. Лазарев, В. А., Степанов. В. Г. международные аспекты логистики: учеб, пособие). - Владивосток : Изд-во ВГУЭС, 2012. - 346 с.

3. Воронов. В. И. Методологические основы формирования и развития региональной логистики: монография. - Владивосток : Изд-во Дальневосточного Университета. 2013. - 316 с.

4. Уваров. С. А. Логистика: общая концепция, теория, практика. - СПБ.: ИНВЕСТ-НП. 2014. - 232 с.

5. Драчева. Е. Л., Либман. А. М. Проблемы глобализации и интеграции международного бизнеса и их влияние на российскую экономику (Текст) // Менеджмент в России и за рубежом. - 2016. - № 4. 